\title{
International legal standards of advocacy in Russian environmental legislation
}

\author{
Irina $\mathrm{Kvach}^{1 *}$ \\ ${ }^{1}$ Yugra state University, Chekhova str., 16, Khanty-Mansiysk, 628011, Russia
}

\begin{abstract}
The article deals with conceptual questions of the role and place that international standards of advocacy take in the system of sources of advocacy in Russia. The author, relying on the decisions of the Plenum of the Supreme Court of Russian Federation, points out the priority importance of international standards and rules in matters of legal regulation of legal proceedings. Considering a significant array of international documents adopted within the framework of international organizations, including the Council of Europe, the author singles out those containing international standards of advocacy. The study of Russian national legislation through the prism of international standards of advocacy makes it possible to conclude that, as a result of prolonged legal reforms, the main fundamental provisions of national legislation have been brought into line with the requirements of international standards, but work in this direction has not yet been over. As a result, the author points out the conceptual role of international treaties as sources of advocacy. The findings became the basis for further author's research of international standards, as a legal basis for the regulation of advocacy to protect the rights and freedoms of indigenous peoples of the north in the development of oil and gas fields on their ancestral lands.
\end{abstract}

\section{Introduction}

The advocacy is traditionally referred to the field of public relations regulated by national law. At the same time, the growing role of international law, due to the processes of globalization and interstate integration, predetermines increasing influence of norms and principles of international law on national legislation. There is a kind of internationalization of legal regulation and unification of legal norms of different states. In this connection, in the doctrinal study of legal regulation of the advocacy, the issues of international legal regulation of these relations become relevant. A detailed analysis of international law, as well as of its compliance with national legislation, will make it possible to draw conclusions about its perfection, about the prospects and directions of development of Russian national law.

Recently, the role of international treaties as sources of national law has taken place in various fundamental legal studies. Those having studied international treaties in the role of sources of constitutional, criminal, criminal procedural law and other branches of law,

\footnotetext{
*Corresponding author: kvachss@yandex.ru
} 
considered general issues of the operation of international law in the national legal system [1]. The constitutional and legal norms of various states have been studied in detail for the implementation of international standards [2]. However, the role and place of international legal standards as regulators of relations in the field of advocacy remain poorly understood, episodic studies reveal only some aspects of the issue under study (Shakirov T.G.) or are an overview of existing documents (Kazanbaeva Z.R.). The author aims to study, in a first approximation, the role and place of international standards of advocacy in the system of legal regulation of the institution of advocacy, as well as to identify conceptual issues of their application in the regulation of legal relations.

\section{Methods}

The synergistic research method, in conjunction with the systemic-structural and formallegal method, made it possible to consider the norms and principles of international law as an integral element of Russian legal system. The theoretical basis of the study was the previously developed author's provisions on the role of international standards of advocacy [For example, 3]. The first stage of the study was a review of the judicial practice of the Plenum of the Supreme Court of Russian Federation, which allowed us to establish the "susceptibility" of Russian legal system to international legal standards of advocacy. At the second stage, international treaties were identified that are carriers of international standards for advocacy. The third stage was the study of the content of national law through the prism of international standards, which made it possible to draw the author's conclusions.

\section{Results}

The article reveals the special legal nature of international standards as regulators of national legal relations. The author comes to the conclusion that the norms of international standards of advocacy act as a kind of "catalyst" for the processes of legal regulation. On the one hand, they are the basis for the legislators in the development of laws and other legal acts, on the other hand, they allow the law enforcement officer to fill in the gaps in the law, which is reflected in Figure 1.

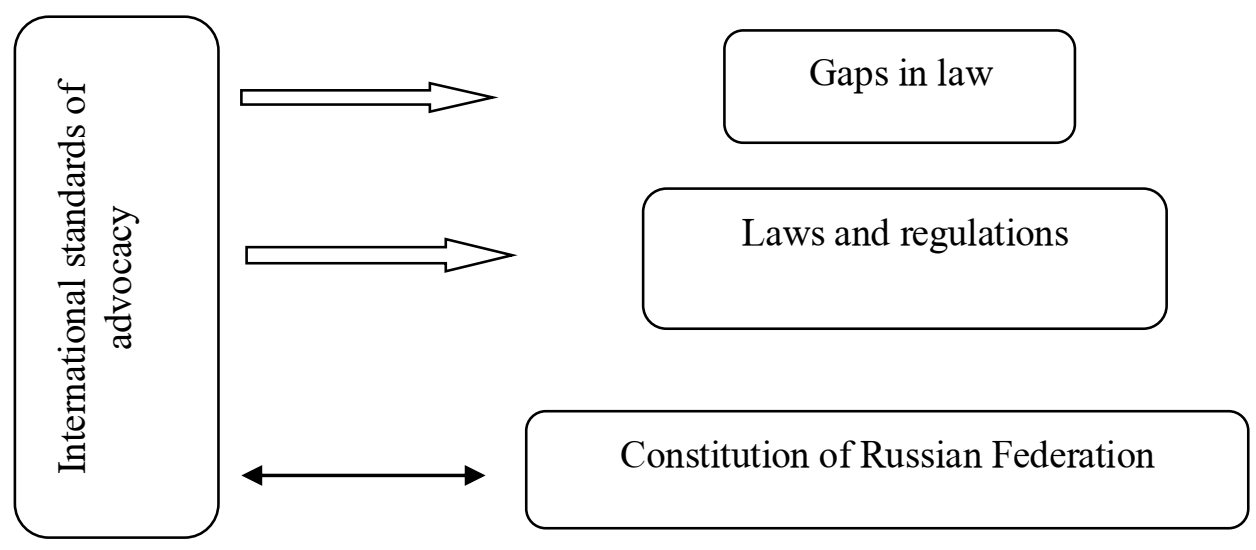

Fig. 1. The role of international standards in law enforcement. 


\section{Discussion}

The main source of law that determines the organization, principles and procedure for the advocacy in Russian Federation is undoubtedly, first of all, Russian legislation. At the same time, both the legislator and the law enforcement officers cannot fail to take into account a significant array of norms of principles and rules developed within the framework of cooperation between states in the international arena, enshrined both in two and multilateral agreements of Russian Federation, and in conventions, declarations and other documents containing generally recognized principles and norms of international law, which the 1993 Constitution defined as "an integral part of the legal system of Russian Federation." In addition, the amendments made in 2020 to Article 69 of the Constitution stipulated that "... The state protects the cultural identity of all peoples and ethnic communities of Russian Federation, guarantees preservation of ethnocultural and linguistic diversity" (Constitution of Russian Federation).

Let's make a reservation right away that international standards of advocacy should be understood as a system of international legal norms and principles recognized by the world community (a significant number of states) that regulate, consolidate and develop relations associated with the organization and implementation of advocacy.

The Russian Constitution establishes the primacy of international law - "if an international treaty of Russian Federation establishes rules other than those provided for by law, then the rules of an international treaty apply", which gives us grounds to define an international legal norm as a priority rule in relation to the norm of national legislation.

Consider the position of the Supreme Court of Russian Federation regarding the application of international standards of advocacy, reflected in the decisions of the Plenum of the Supreme Court of Russian Federation and decisions of the Supreme Court of Russian Federation.

In the decisions of the Plenum of the Supreme Court of Russian Federation, it is repeatedly stated that "international treaties are one of the most important means of developing international cooperation, contribute to the expansion of international relations with the participation of state and non-state organizations, including with the participation of subjects of national law, including individuals" (Resolutions of the Plenum of the Supreme Court Court of Russian Federation No. 5 dated October 10, 2003). In addition, this decree indicates the primary role of international treaties as defining documents in the protection of human and civil rights and freedoms. The plenary session points to the obligation to further improve judicial activity by implementing the positions and requirements of international law at the domestic level. To achieve a correct and uniform understanding and application of international standards by the courts in the administration of justice, the Plenum of the Supreme Court of Russian Federation decides to provide the following clarifications:

1. In the Russian Federation, human and civil rights and freedoms are recognized and guaranteed in accordance with the generally recognized principles and norms of international law and in accordance with the Constitution of Russian Federation (part 1 of Article 17 of the Constitution of Russian Federation).

Based on the very definition of advocacy, contained in the relevant law, that such is "qualified legal assistance ... in order to protect their rights, freedoms and interests, as well as to ensure access to justice" (Federal Law of 31.05.2002 N 63- Federal Law (as amended on July 29, 2017) On advocacy and legal profession in Russian Federation), we single out a group of international legal documents in the field of human rights, as one of the main "carriers" of international standards for advocacy. Of great importance is the definition by the Plenum of the Armed Forces of Russian Federation of the definition of "generally recognized principles of international law", which are designated as "fundamental 
peremptory norms of international law, adopted and recognized by the international community of states, in general, deviation from which is unacceptable." Thus, the Plenum of the Armed Forcesof Russian Federation points to the imperative establishment of the mandatory observance by the courts of the generally recognized principles of international law in the administration of justice, which makes it possible to apply them as norms of direct action in carrying out lawyers' activities. In this case, we are talking, first of all, about such generally recognized principles of international law as: the principle of universal respect for human rights and the principle of conscientious fulfillment of international obligations.

The generally recognized norm of international law is defined by the Plenary Session as "a rule of conduct accepted and recognized by the international community of states as a whole as legally binding."

2. International treaties of Russian Federation, as well as generally recognized principles and norms of international law, are an integral part of legal system of Russian Federation. The Plenum of the Armed Forces of Russian Federation indicates that when the court administers justice, within the framework of civil, administrative and criminal proceedings, the international treaty of Russian Federation, which entered into force and became binding on Russia and the provisions of which do not require the issuance of a special domestic act, is applied equally with the norm of national law. We are talking about both agreements concluded on behalf of Russian Federation, and intergovernmental and interagency agreements.

3. The courts are obliged to apply only international treaties that have entered into force, in the manner prescribed in the treaty, or in the manner established by Article 24 of the Vienna Convention on the Law of Treaties of 1969 [4] and the Federal Law "On International Treaties of Russian Federation" (Federal Law of July 15, 1995 No. 101).

4. Attention is drawn to a whole list of international treaties that have direct and immediate effect in the legal system of Russian Federation. At the same time, the courts must take into account that consent to the binding nature of an international document for Russian Federation must be expressed in the form of a federal law.

5. International treaties, the norms of which provide for elements of a criminal offense, cannot be directly applied by the courts. A review of international documents carried out in the framework of this study showed the presence of these norms in the following documents: the 1961 Single Convention on Narcotic Drugs [5], the 1971 Convention on Psychotropic Substances [6], the 1979 International Convention against the Taking of Hostages [7], 1970 Convention for the Suppression of Unlawful Seizure of Aircraft [8], 2000 United Nations Convention against Transnational Organized Crime [9], 2000 Protocol against the Smuggling of Migrants by Land, Sea and Air [10].

In accordance with the basic principles of national criminal law, international legal norms, which provide for signs of corpus delicti, can be applicable in Russian Federation only if the norm of the Criminal Code of Russian Federation directly indicates the need to apply an international treaty of Russian Federation (in particular, Articles 355 and 356 of the Criminal Code of Russian Federation).

6. The Plenum of the Armed Forces of Russian Federation indicates the need to comply with the principle of the primacy of international law.

7. In the resolution of the Plenum of the Armed Forces of Russian Federation, attention is drawn to the fact that the incorrect application of international law by a court may have consequences in the form of cancellation or change of the court's decision.

8. To resolve difficulties in interpreting the provisions of international law, the Plenum of the Armed Forces of Russian Federation recommends using acts and decisions of international organizations. 
9. When carrying out additional education for judges and court staff, the Plenum of the Armed Forces of Russian Federation recommends paying special attention to the study of international standards of advocacy.

As we can see, the position of the Plenum of the Armed Forces of Russian Federation unambiguously determines the priority importance of international standards and rules in matters of legal regulation of legal proceedings. Modern processes of globalization and interstate integration also bring to the fore the need to establish rules binding on different states, which are aimed at interaction in a wide variety of spheres of life, including in the implementation of human rights activities. Such rules are enshrined in bilateral and multilateral agreements.

The basis of legal regulation of advocacy in Russian Federation is its internal legislation, while Article 15 of the Constitution of Russian Federation, adopted in 1993, cited several times earlier, predetermines the construction of a system of law corresponding to the universal principles and norms of international law, mandatory for many states and other subjects.

A little later, in 1996, Russia's accession to the Council of Europe raised the issue of bringing the entire system of Russian substantive and procedural law in line with international legal standards and other international obligations assumed. The conclusion prepared at the request of Russia to join the Council of Europe unambiguously confirmed that the legal system of Russia suffers from a number of shortcomings, and when finalizing the most important legal acts (the Criminal Code, the Criminal Procedure Code, the Civil Code, the Code of Civil Procedure of Russian Federation), their concept will be based on the principles and standards of the Council of Europe ... In addition, with regard to the advocacy, a separate clause was indicated that predetermined the legislative protection of the status of a lawyer and the establishment of a professional association of lawyers.

Having signed the Agreement on Cooperation in Fighting Crimes in the Sphere of the Economy in 1996, Russia undertook obligations to bring national legislation in line with the requirements of the said Agreement, which regulate the issues of "confiscation and transfer of assets to other Parties (securities, jewelry, antiques and other material values) obtained as a result of criminal activity; conditions and procedure for providing other Parties with banking, credit and financial and other documents in order to prevent, detect, suppress and disclose crimes in the economic sphere. "

Subsequently, in the process of active and prolonged legal reforms, the main fundamental provisions of national legislation were brought into line with the requirements of international standards, but work in this direction has not yet been completed.

Russian legal science has repeatedly conducted research on many provisions of international documents adopted under the auspices of the UN and the Council of Europe, which enshrine a whole array of basic international principles that are binding on all member states of these organizations. Among the main such principles should be called: strict observance of the rule of law, the principle of universal equal justice, truth and consistency, equality of all subjects, tolerance, openness (publicity), competitiveness of the parties, the principle of involving various members of the public in the criminal process, the principle of respect for human honor and dignity, the principle of personal inviolability, the protection of human and civil rights and freedoms in criminal proceedings, the provision of effective legal assistance, the inviolability of private, personal and family life, the principle of the presumption of innocence, the principle of freedom of appeal against procedural actions and decisions, a number of principles with regard to the freedom of choice by each participant in the process of the language of criminal proceedings.

At the same time, as indicated, the list of principles enshrined in international acts, the Constitution of Russian Federation and the Criminal Procedure Code of Russian Federation, which should be applied in criminal proceedings, is not identical, but despite 
the fact that in accordance with Russia's international obligations, all the principles enshrined in international acts, must find application in criminal proceedings (Tatyanin D. $\mathrm{V}$. in the article "The concept of international principles in criminal proceedings", 2014).

International legal acts that establish general principles for the provision of legal assistance and the activities of lawyers are one of the main sources regulating the advocacy (Sintsov, G. V. In the article "Features of International Legal Acts Regulating the Advocacy", 2013).

Let us consider some of the basic generally recognized principles of international law, which formed the basis for the Russian legislation on the legal profession, criminal procedure legislation and a number of other legislative acts regulating advocacy.

First of all, it is necessary to focus on the fact that the influence of international law on advocacy and national legal proceedings is determined by the ability of a lawyer or his client to apply to the European Court of Human Rights, if the national courts did not protect his rights and legitimate interests.

It is necessary to point out that the implementation by Russian Federation of the international standards it has undertaken provides for an obligation on the part of state bodies, if necessary, to take private measures aimed at eliminating violations of human rights stipulated by the Convention for the Protection of Human Rights and Fundamental Freedoms (1950) [11], and the consequences of these violations for the applicant, as well as general measures in order to prevent the recurrence of such violations. The judicial authorities, within the limits of their competence, must act in such a way as to ensure the fulfillment of the obligations of the state arising from the participation of Russian Federation in the Convention for the Protection of Human Rights and Fundamental Freedoms.

In case, during the trial, circumstances are revealed that contributed to the violation of the rights and freedoms of citizens guaranteed by the Convention, the court has the right to issue a special ruling, which draws the attention of the relevant organizations and officials to the circumstances and facts of violation of these rights and freedoms requiring the necessary measures.

The principle of "non bis in idem" enshrined in international law is associated with the inadmissibility of multiple trials against the accused. So, Art. 4 of Protocol 7 of the European Convention for the Protection of Human Rights and Fundamental Freedoms, specifies that "no person should be re-tried or criminally punished under the jurisdiction of the same state for a crime for which this person has already been finally acquitted or convicted in accordance with the law and criminal - procedural norms of this state". These provisions do not prohibit the reconsideration of the case if there is information about new or newly discovered circumstances or if in the course of the previous proceedings there were significant violations that influenced the outcome of the case (part 2, article 4).

The implementation of this provision is reflected in paragraph 4 of Article 27 of the Code of Criminal Procedure of Russian Federation, where, as one of the grounds for terminating criminal prosecution, it is indicated "the existence of a verdict against the suspect or the accused who has entered into legal force on the same charge or a court ruling or a judge's decision to terminate criminal case on the same charge".

Provisions part 2. Article 4 of the above mentioned document, in terms of allowing the re-examination of the case on newly discovered circumstances, are enshrined in Chapter 49 of the Criminal Procedure Code of Russian Federation.

Article 6 of the European Convention for the Protection of Human Rights and Fundamental Freedoms, enshrining the right to a fair trial, regulates that "everyone, in case of a dispute about his civil rights and obligations, or when any criminal charge is brought against him, has the right to a fair and public hearing in a reasonable term ... ". 
In this case, the publicity of the consideration of the case predetermines the publicity of the process.

The position of this international legal standard is reflected both in the text of the Constitution of Russian Federation and in the relevant procedural legislation. Thus, Article 123 of the Constitution of Russian Federation states: "the proceedings in all courts are open ...". Similar provisions are enshrined in Article 241 of the Code of Criminal Procedure of Russian Federation, Article 10 of the Code of Civil Procedure of Russian Federation, Article 11 of the Code of administrative legal proceedings and in a number of other regulatory legal acts of a material and procedural nature.

At the international legal level, special attention is paid to the adversarial principle, where it is considered as one of the fundamental conditions of fair justice (paragraph 1 of article 14 of the International Covenant on Civil and Political Rights, paragraph 1 of article 6 of the Convention on the Protection of Human Rights and freedoms). It was reflected in a number of decisions of international judicial bodies. International law determines the essential importance of the adversarial principle for determining the rights and obligations of the parties.

Despite Russia's striving for the compliance of national law with its international legal obligations, it was only in 2001, as a result of many years of discussions, that the Criminal Procedure Code of Russian Federation was adopted, which recognized the principle of adversarialness of the parties as the defining beginning of criminal proceedings.

Article 11 of the Universal Declaration of Human Rights establishes for every person accused of committing a crime the right to be presumed innocent until the guilt is established by law through a public trial, in which this person is provided with all the opportunities for defense.

This rule lays down the presumption of innocence - one of the basic principles of Russian criminal law and the principle of the need to ensure the suspect and the accused have the right to defense. It was reflected in Art. 45, 46, 48 of the Constitution of Russian Federation, art. 16 of the Criminal Procedure Code).

The Supreme Court of Russian Federation has consistently recognized the fact that the accused did not provide the right to invite a defense lawyer of his choice as a significant violation of the criminal procedure law; sees a violation of the law also in the fact that instead of the chosen lawyer, another defense lawyer should carry out defense.

The 1985 Declaration on Basic Principles of Justice for Victims of Crime and Abuse of Power recommends the adoption of measures at the international and national levels to improve access to justice and fair treatment, reparation, compensation and assistance for victims of crime. Similar requirements are contained in the Basic Provisions on the Role of Lawyers, adopted in August 1990 in New York by the 8th United Nations Congress on Crime Prevention, which are formulated to assist participating States in promoting and ensuring an appropriate role for lawyers that must be respected. guaranteed by governments in the development of national legislation and its implementation, and must be taken into account by both lawyers and judges, prosecutors, members of the legislative and executive branches and society.

In addition, Part 2 of Article 11 of the Universal Declaration of Human Rights defines the principle of the operation of criminal legislation in time - "no one can be convicted of a crime on the basis of committing any act or for inaction that, at the time of their commission, did not constitute a crime under national laws or under international law. Nor can a more severe punishment be imposed than that which could have been applied at the time when the crime was committed."

This provision without costs is enshrined in Art. 9 of the Criminal Code of Russian Federation. It is worth agreeing with the criticism, justified in our opinion, regarding the consolidation of this most important principle of criminal law, arising from the direct 
requirements of international standards of law, outside the first chapter of the criminal code, which enshrines the tasks and principles of the Criminal Code of Russian Federation.

In accordance with Art. 3 of the Convention on the Transfer of Sentenced to Deprivation of Liberty for Further Serving of Sentence, 1998, the conviction of a person and his whereabouts must be notified in writing, respectively, by the court and the body executing the sentence, diplomatic missions or consular offices of the state of which the convicted person is or on whose territory he permanently resides. (if he is a stateless person), as well as his close relatives, legal representative and lawyer for the exercise of their rights to apply for the transfer of a person sentenced to imprisonment for serving a sentence in the state of citizenship. This norm of the cited document, developed in 1998 within the framework of the CIS, is reflected in Article 17 of the Code of Criminal Procedure of Russian Federation adopted in 2001. It should be noted that a number of provisions of this treaty were adopted on the basis of the provisions of the Convention on the Transfer of Sentenced Persons, adopted in Strasbourg in 1983.

\section{Conclusion}

Thus, the considered issues of the influence of international standards on the formation of Russian legislation in the field of regulation of advocacy allow us to draw following conclusions:

1. International standards establish basic principles and rules that the legislator of each state party to the agreement must adhere to, while national legislation specifies these principles, securing the relevant norms in the Constitution and criminal and criminal procedure legislation.

2. The legal acts adopted in Russia after 1993 mainly take into account the main provisions of international standards.

3. International legal norms can be applied by a lawyer participating as a representative of a client in constitutional, civil and administrative proceedings, a defender of a client in criminal proceedings in cases of administrative offenses as norms of direct action (with the exception of those norms that provide for signs of criminal offenses), for example, in the case of a gap in national legislation, or a contradiction between the norms of national law and international legal norms.

\section{References}

1. A.Ya. Kapustin, I.P. Zhuravlev Moscow magazine of international law 1, 26-43 (2020) DOI: 10.24833/0869-0049-2020-1-26-43

2. S. Kvach, N. Frolova, E. Vasilkova, The European Proceedings Of Social \& Behavioural Sciences. III International Scientific Symposium. National Research Tomsk Polytechnic University,411-415 (2017) DOI: 10.15405/epsbs(23571330).2017.1

3. I.V. Kvach, I.N. Fedulov, Issues of sustainable development of society 9, 324-330 (2020) DOI: 10.34755/IROK.2020.49.67.048

4. S.N. Haryuchi, Journal of Russian law 7, 13-22 (2006)

5. S.N. Haryuchi, Indigenous minor peoples: legal issues (Tomsk University Press, Tomsk, 2004)

6. N.G. Shishatsky, V.I. Kirko, A.V. Keus, Arctic and North 7, 178-184 (2012)

7. E. Yerokhina, V. Alekseev, Problems of theory and practice of management 8, 67-80 (2017) 
8. I.E. Lapshina, Scientific and methodological electronic journal "Concept" 26, 566-570 (2014)

9. M.A. Khvatova, A.M. Rabac, The Lawyer 19, 7-11 (2015)

10. M.Yu. Karaseva, International journal of applied and fundamental research 10-1, 158 161 (2016)

11. P.O. Panfilov, Actual problems of Russian law 1(98), 146 - 155 (2019)

12. A.V. Kopytova, N.S. Zotkina, I.G. Reshetnikova, MATEC Web of Conferences 239, 04012 (2018) DOI: 10.1051/matecconf/201823904012

13. V. Lez'Er, N. Semeryanova, A. Kopytova, I. Kvach, E3S Web of Conferences 110, 02094 (2019) DOI: 10.1051/e3sconf/201911002094

14. R. Kolobov, U. Filatova, V. Borshcheniuk, N. Semerianova, D. Bayanov, E3S Web of Conferences 110, 02095 (2019) DOI: 10.1051/e3sconf/201911002095

15. Y.V. Truntsevsky, I.I. Lukiny, A.V. Sumachev, A.V. Kopytova, MATEC Web of Conferences 170, 01067 (2018) DOI: 10.1051/matecconf/201817001067

16. N. Semeryanova, O. Fedorenko, A. Kopytova, MATEC Web of Conferences 239, 04013 (2018) DOI: 10.1051/matecconf/201823904013 